\section{Seed vigor in performance of wheat plants: evidence of interaction with nitrogen}

\author{
José Ricardo Bagateli ${ }^{1 *} \mathbb{D}$, Gabriel Streck Bortolin ${ }^{1} \mathbb{D}$, Ricardo Mari \\ Bagateli $^{2} \mathbb{D}$, Jader Job Franco ${ }^{1}\left(\mathbb{D}\right.$, Francisco Amaral Villela ${ }^{1} \mathbb{D}$, Geri Eduardo \\ Meneghello ${ }^{1}$
}

ABSTRACT: The use of high-quality seeds is an important factor in the crop production system. Its benefits to the performance of plants and possible interactions with other factors - such as nitrogen fertilization - could be better understood from a multivariate analysis perspective. With this approach, the objective of this work was to evaluate the impacts of wheat seed vigor and possible interactions with nitrogen fertilization on the performance of wheat plants. The data analyzed were obtained from the average results gathered through three experimental environments, located in the department of Alto Paraná, Paraguay. High-vigor seeds with provided a better plant stand and also a greater growth in the formed tillers stage. This category also provided plants with higher performance - a condition found for dry matter weight - in the booting, flowering and milk seed stages, in the presence and absence of nitrogen fertilization. The multivariate analysis showed that plants originating from high-vigor seeds that had not been fertilized with $\mathrm{N}$ showed a similar performance to that of low-vigor plants, but fertilized with $\mathrm{N}$. High-vigor wheat seeds provide plants with superior performance.

Index terms: Triticum aestivum, seed quality, established plants, yield components, principal component analyses.

RESUMO: A utilização de sementes de alta qualidade constitui um importante fator no sistema de produção de grãos. Seus benefícios ao desempenho das plantas e possíveis interações com outros fatores - ao exemplo da fertilização nitrogenada - poderiam ser mais bem compreendidos a partir do uso de análise multivariada. Com essa abordagem, o objetivo do trabalho foi avaliar os impactos do vigor de sementes de dois genótipos de trigo e as interações com a fertilização nitrogenada no desempenho de plantas de trigo. Os dados analisados foram provenientes de resultados obtidos em três ambientes experimentais, localizados no departamento de Alto Paraná, Paraguai. Sementes com alto vigor proporcionaram melhor estande de plantas e maior crescimento no estágio de afilhos formados. Proporcionaram também plantas com maior desempenho vegetativo e reprodutivo - condição verificada a partir da massa de matéria seca - nos estágios de emborrachamento, florescimento e de grão leitoso, tanto na presença quanto na ausência da fertilização nitrogenada em cobertura. A análise multivariada permitiu constatar que plantas originadas de sementes com elevado vigor e não fertilizadas com $\mathrm{N}$ em cobertura apresentaram desempenho semelhante ao de plantas provenientes de baixo vigor, mas fertilizadas com $\mathrm{N}$ em cobertura. Sementes de trigo com alto vigor proporcionam plantas com desempenho superior.

Termos para indexação: Triticum aestivum, qualidade de sementes, estande de plantas, componentes do rendimento, análise de componentes principais.
Journal of Seed Science, v.44, e202244001, 2022

http://dx.doi.org/10.1590/ 2317-1545v44253465
${ }^{*}$ Corresponding author
E-mail: ricardobagateli@gmail.com

Received: 6/20/2021.

Accepted: 11/16/2021.

${ }^{1}$ Universidade Federal de Pelotas, Caixa Postal 354, 96010-900 Pelotas, RS, Brasil.

${ }^{2}$ Universidade Tecnológica Federal do Paraná. 85660-000 - Dois Vizinhos, PR, Brasil. 


\section{INTRODUCTION}

The challenges for food production until 2050 have intensified the need to improve production per unit of arable area, and seeds play a key role in this context. Peske et al. (2012) consider them as "chips" for their ability to propagate important technologies, and the success in bringing these benefits to production systems is directly dependent on the quality of the seed used at the time of sowing.

The benefits of using seeds with high physiological performance, also called high-vigor seeds, include adequate and uniform stands, consisting of plants (or seedlings) that are vigorous and efficient in taking advantage of available resources. On this important topic, recent studies with seed-producing species have found that the benefits of using high-vigor seeds are not limited only to establishment and initial growth; they can also be observed in crop yields (Caverzan et al., 2018; Bagateli et al., 2019; Ebone et al., 2020).

When crop performance assessment is based on seed quality, plant characterization allows identifying at a time the impacts generated by quality that are more expressive in contributing to productivity. In wheat (a species with outstanding worldwide nutritional, the use of high-vigor seeds favors the establishment of plant stand (Marinho et al., 2021) and the growth and development of plants in the initial phenological stages, culminating in an increase in seed yield (Abati et al., 2018). Also in wheat, Cardoso et al. (2021) went beyond yield and investigated the impacts of vigor on seed quality.

Conducting evaluations throughout the cycle also helps to shed light on possible interactions between the quality of seeds used in sowing and other factors, e.g., nitrogen fertilization in cereals. In the study by Bohn et al. (2020), in stands whose initial evaluations showed lower growth, seed production was similar to that of the best stands, after the use of nitrogen fertilization.

The possible impacts of seed vigor, as well as its interaction with other relevant factors, such as nitrogen fertilization, at different times throughout the plant cycle, could be better elucidated by means of a multivariate approach. In this case, principal components analysis appears as an important alternative for such understanding. On this interesting approach (principal component analysis), Bertolli et al. (2013) found that the use of cross-scale multivariate analysis made it possible to establish models for the systemic understanding of interactions between plants and their changing environment.

The hypothesis of this study is that wheat plants from high-vigor seeds have better establishment, greater initial growth, and higher productivity than wheat plants from low-vigor seeds, regardless of the presence or absence of nitrogen fertilization. Therefore, the objective of this work was to verify the impacts of wheat seed quality and the interaction with nitrogen fertilization throughout the crop cycle, using traditional analysis (ANOVA) and multivariate analysis.

\section{MATERIAL AND METHODS}

This study was conducted in three experimental sites, distributed in different municipalities of the Department of Alto Paraná - Paraguay; Los Cedrales, (latitude 2539'07.2 S, longitude 5443'00.6 W and altitude 224 m); Santa Rita (latitude $25^{\circ} 40^{\prime} 58.0 \mathrm{~S}$, longitude $54^{\circ} 43^{\prime} 30.1 \mathrm{~W}$ and altitude $214 \mathrm{~m}$ ); and Naranjal (latitude $25^{\circ} 53^{\prime} 35.1 \mathrm{~S}$, longitude $55^{\circ} 20^{\prime} 10.8 \mathrm{~W}$ and altitude $274 \mathrm{~m}$ ).

In all three locations, there was a predominance of clayey soil, classified as Oxisol according to the American classification (Soil Taxonomy) adopted in Paraguay (López et al., 1995). In the current Brazilian classification of soils, it is considered to belong to the Latosol class (EMBRAPA, 2013). The soil at the experimental sites of Los Cedrales, Santa

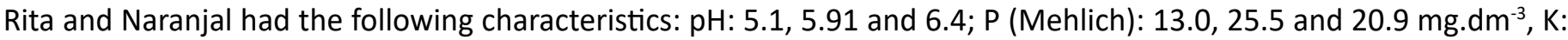

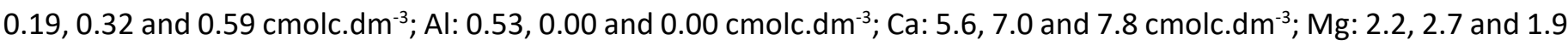
cmolc.dm ${ }^{-1}$ and organic matter of 2.2, 3.1 and $3.0 \%$, respectively.

According to the Köppen classification, the predominant climate in the region covering the three experimental sites is Cfa - humid subtropical (mesothermal) climate. Rains occur more frequently in spring and summer, with no defined 
dry season. The average annual rainfall is $1,500 \mathrm{~mm}$, and the monthly average temperature ranges from 17 to $27^{\circ} \mathrm{C}$ (López et al., 1995). Figure 1 shows the temperature and precipitation variables, collected throughout the experiment at each location.
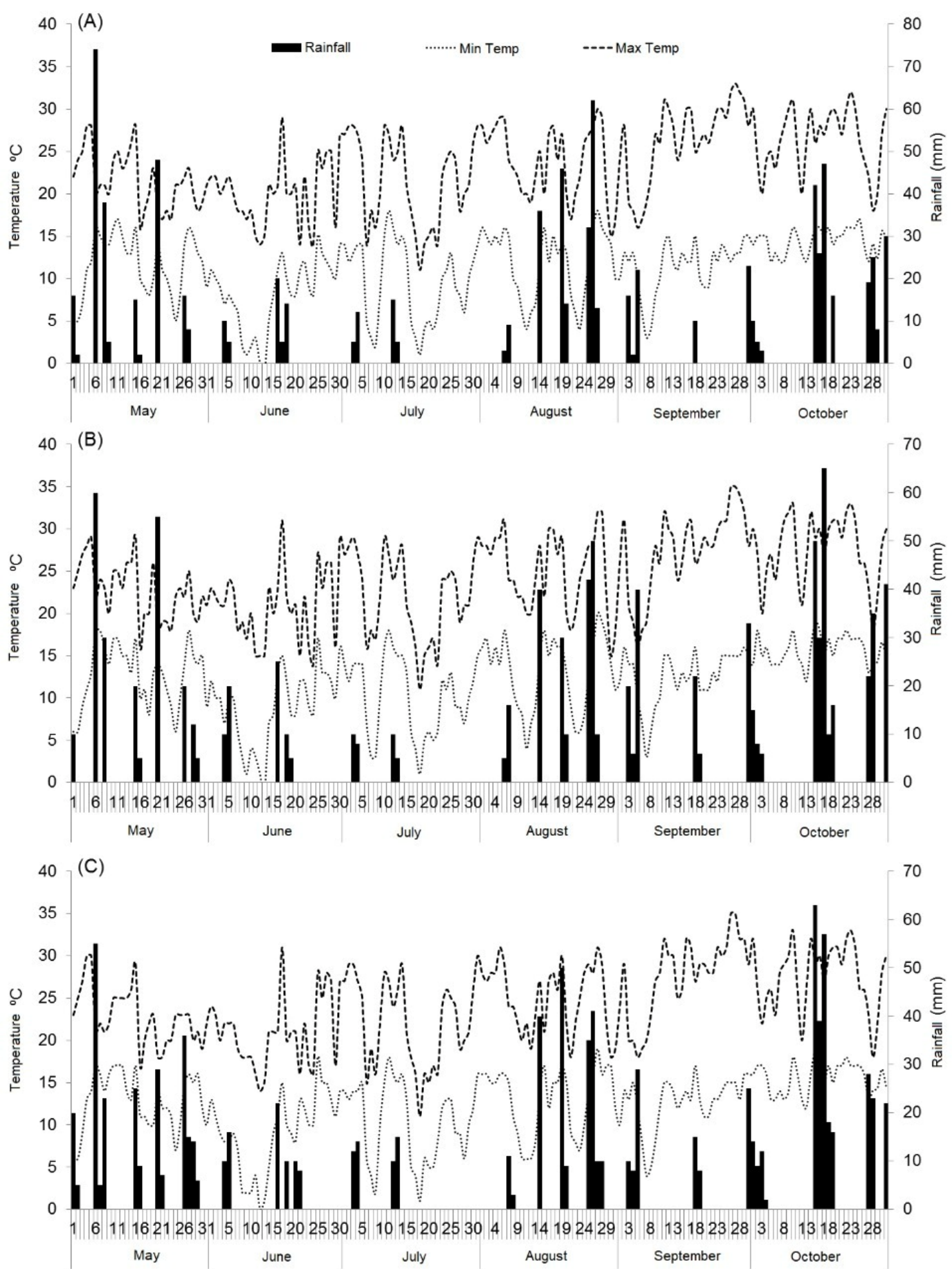

Figure 1. Daily values of (maximum and minimum) temperature and precipitation during the experimental period conducted in 2016 - in the municipalities of Los Cedrales (A), Santa Rita (B) and Naranjal (C), located in the Department of Alto Paraná - Paraguay. 
The genotypes CD 150 (early cycle) and Tbio Mestre (medium cycle) - both registered, protected and indicated for cultivation in Brazil and Paraguay - were evaluated. These genotypes have distinct and contrasting agronomic characteristics. CD 150 reaches flowering at 58 days and its physiological maturation occurs approximately at 114 days after emergence. It is short, with average height of $68 \mathrm{~cm}$; Tbio Mestre, on the other hand, reaches flowering at 78 days and maturation at 140 days after emergence. At $85 \mathrm{~cm}$, its height is rated as average.

The seeds of the genotypes were purchased from commercial lots, analyzed 30 days before the installation of the experiments and classified into vigor levels by the accelerated aging and germination test. For the "vigor" factor, lots of the two genotypes were selected with accelerated aging test results of $90 \%$ (high vigor), $80 \%$ (intermediate vigor), $70 \%$ (low vigor), and $60 \%$ (very low vigor). The germination rate of these same lots was similar and above $85 \%$. The experiments were installed in a direct seeding system in straw after soybean harvest. Sowing took place at the time indicated for the genotypes. In Los Cedrales, it took place on the 5th of May; in Santa Rita, on May 14th; and in Naranjal, on the 6th of June.

Basic chemical fertilization was performed together with sowing by applying $300 \mathrm{~kg}^{-h^{-1}} \mathrm{of}$ the formulated fertilizer $\mathrm{N}: \mathrm{P}_{2} \mathrm{O}_{5}: \mathrm{K}_{2} \mathrm{O}$ in a 10-20-10 ratio, as indicated by Pavinato et al. (2017) and based on the interpretation of the chemical analysis of the. The seeds used for sowing were treated with tebuconazole $\left(1.3 \mathrm{~g} \cdot \mathrm{L}^{-1}\right)$ and imidacloprid $\left(23.3 \mathrm{~g} \cdot \mathrm{L}^{-1}\right)$ at a rate of $2.5 \mathrm{ml} \mathrm{per} \mathrm{kg}{ }^{-1}$ of seeds. At the time of sowing (which was mechanized), the distribution of 80 seeds per meter - from each lot and in each experimental location - was recommended.

The presence and absence of nitrogen $(\mathrm{N})$ in top dressing was also evaluated. For the presence of $\mathrm{N}$, topdressing fertilization was performed with $45 \mathrm{~kg} \mathrm{~N} . \mathrm{ha}^{-1}$ at the beginning of tillering, using solid urea fertilizer. During the crop cycle, the crop treatments followed the technical recommendations for wheat production in the region, keeping the plants free from pests and diseases that could interfere in the development of the crop.

In each of the three experimental sites, the experiment used a randomized block split-plot design.

Each experimental unit was formed by 12 seeding rows with $15.0 \mathrm{~m}$ in length, spaced $0.17 \mathrm{~m}$ apart. To avoid the border effect, the usable area of the plot was composed of 10 central rows with $6.0 \mathrm{~m}$ in length, in a total of $10.2 \mathrm{~m}^{2}$ per experimental unit. The phenological stages of the crop were determined using the Feekes scale, illustrated and modified by Large (1954). To evaluate the possible impacts caused by the treatments, plant population (POP) was evaluated in the Feekes (F) 1 stage by counting the total number of plants present in two linear meters of the 6 central rows of the usable area of the plot, and the results were expressed in number of plants per $\mathrm{m}^{2}$.

A total of 40 plants in each plot were measured to determine height (HGT) - with the aid of a millimeter ruler at the beginning of tillering, as well as in stages F3 (formed tillers), F8 (booting, visible flag leaf); and reproductive: F10.5.1 (flowering). In these same stages, the Normalized Difference Vegetation Index (NDVI) was also determined, with readings performed with a GreenSeeker ${ }^{\circledR}$ sensor. For this assessment, the device was positioned parallel to the crop lines, at a height of approximately $0.50 \mathrm{~m}$ above the top of the plant canopy.

In addition to the non-destructive evaluations, plant dry matter weight (DMW) was evaluated in stages F3, F8, F10.5.1 and F11.1. These evaluations took place by collecting the shoot of the plants in a rectangular strip placed transversally within the usable area of the plot, consisting of 6 rows with $0.25 \mathrm{~m}$ in length, in a total of $0.25 \mathrm{~m}^{2}$. Soon after collection, the plants were dried artificially by the greenhouse method with forced air circulation at $70{ }^{\circ} \mathrm{C}$ for 48 hours. At the end of this period, dry matter weight was evaluated on a scale with a precision of $0.01 \mathrm{~g}$, and the results were expressed in $\mathrm{g}$ dry mass $\mathrm{m}^{2}$. The number of tillers per plant (AF) - determined in stage F8 - was counted in a total of 40 plants present in the usable area of the plot. The results were expressed in number of tillers. plant ${ }^{-1}$.

Assessments to determine the reproductive performance of plants were conducted in stage F11.4. The number of spikelets per ear (NSpE) was counted in 40 ears originating from the main stalk of 40 plants present in the usable area of the plot, and the results were expressed in number of spikelets ear ${ }^{-1}$. These same ears allowed counting the number of seeds per spikelet (NSSp), and their results were expressed in number of seeds spikelet ${ }^{-1}$. Weight of seeds per ear (WSE) was also determined by weighing the seeds of the ears. In this evaluation, moisture was corrected to $13 \%$, based 
on the moisture values obtained at harvest. The results were expressed in g.ear ${ }^{-1}$. Seed count was used to determine the number of seeds per ear (NSE), and the results were expressed in number of seeds on the ear-1.

Yield (YLD) was determined by harvesting the seeds in 10 sowing rows along a length of $3 \mathrm{~m}$, in a total area of $5.1 \mathrm{~m}^{2}$. In this procedure, all ears were manually harvested and mechanically threshed. After this procedure, moisture content was determined in a Gehaka ${ }^{\circledR}$ G650i seed moisture analyzer. The weight determined in each plot was transformed into $\mathrm{kg}$.ha ${ }^{-1}$, with moisture correction to $13 \%$. The harvest index $(\mathrm{HI})$ was determined at this same moment by collecting 40 plants that, after being threshed, were separated into seeds and vegetative material. The shoot was dried in a forced air circulation oven at $70{ }^{\circ} \mathrm{C}$ to constant weight, and then weighed separately. The results were obtained by applying the formula: $\mathrm{HI}=$ seed weight / shoot dry matter weight, and were expressed in $\mathrm{g}$ seed $\mathrm{g}$ dry matter ${ }^{-1}$.

The analysis of the data - collected from an experiment in a randomized block design with split plots - showed possible interactions between the factors seed vigor and $\mathrm{N}$ ( $4 \times 2$ factor) which were evaluated separately for each genotype. In this procedure, each treatment consisted of four replications. Each unit was composed of the average value obtained in the three experimental locations. In compliance with the assumptions of homogeneity, the data underwent analysis of variance and, when significant, were analyzed by the Tukey's test, with a probability level of $5 \%$, using the Sisvar statistical program (Ferreira, 2019).

The analyses were also based on principal component analysis and hierarchical clusters that were used to design a heat map. For these last two analyses, the data were transformed using the following formula ( $\mathrm{x}$ - mean) / sample standard deviation. The R software (R Core Team, 2018) and the Heatmapper server (Babicki et al., 2016) aided the respective analyses.

\section{RESULTS AND DISCUSSION}

The use of high vigor seeds promoted better establishment of the two evaluated genotypes, and this benefit was found in the established plant population (Table 1). In high-vigor seeds - for both genotypes - the number of plants per unit area was $14 \%$ higher compared to seeds with very low vigor. In a review of the role of seeds in crop performance, Finch-Savage and Bassel (2016) pointed out that crop yield and resource use efficiency depended on the successful plant establishment in the field, and seed vigor was the factor that defined the ability of plants to germinate and quickly establish seedlings.

Plant stand is important for obtaining high yields in large crops, and it is one of the first variables to benefit from seed quality. In agreement with the findings reported in this study, Abati et al. (2017) reported that the use of highvigor seeds provided greater seedling emergence in comparison to low-vigor ones, in two sowing densities. Higher germination speed - as well as emergence - are hallmarks of high vigor, and this strengthens the need to identify physiological quality markers - a theme highlighted by Corbineau (2012) - to choose seed lots with higher performance.

The assessments that characterized the vegetative performance of the crop - height (HGT), normalized difference vegetation index (NDVI) and dry matter weight (DMW) of the plants - show that top dressing application of $\mathrm{N}$ did not show any interaction with seed vigor levels; that is, there were seed quality benefits both in the presence and absence of $\mathrm{N}$ in topdressing fertilization. A comparison, based on the average between vigor levels, among plants originating from seeds with very low quality, plants from the early genotype and those originating from high-vigor seeds, showed that the latter had an increase in DMW of 32, 20, 9 (non-significant) and 21\% in stages F3, F8, F10.5.1 and F11.1, respectively (Table 2). When performed for the medium cycle genotype, this same comparison (high vigor vs. very low vigor) showed that plants from seeds with greater vigor had an increase in DMW of 25, 26, 6 and $23 \%$ in the same four stages of evaluation, respectively.

Although topdressing nitrogen fertilization in grasses has some potential for repair in plant stands that are lagged by the low quality of seeds - and this was evidenced by Bohn et al. (2020) - the results of the present study suggest that plants originated from high-vigor seeds are more efficient in the use of $\mathrm{N}$ and its conversion into DMW. Results from 
recent research show that the speed of initial growth - observed in this study for high-vigor seeds - can influence the use of N. On this topic, Pang et al. (2013) found that the use of wheat genotypes with high initial vigor can improve the efficiency of $\mathrm{N}$ use for biomass production, in addition to improving $\mathrm{N}$ uptake during initial growth.

Table 1. Wheat plant population, height and normalized difference vegetation index (NDVI) - the latter two found in stages 3,8 , and 10.5 .1 on the Feekes scale - and the number of tillers are all variables obtained from plants of the CD 150 early cycle genotype (Cycle -) and the medium cycle Tbio Mestre (Cycle + ) originated from seeds with high vigor $(\mathrm{Hi})$, intermediate vigor $(\mathrm{In})$, low $(\mathrm{L})$ and very low vigor $(\mathrm{VL})$, fertilized $(+\mathrm{N})$ and not fertilized $(-\mathrm{N})$ with nitrogen topdressing.

\begin{tabular}{|c|c|c|c|c|c|c|c|c|c|c|c|c|}
\hline \multirow{3}{*}{ Vigor } & \multicolumn{6}{|c|}{ Cycle - } & \multicolumn{6}{|c|}{ Cycle + } \\
\hline & $-N$ & $+N$ & Mean & $-N$ & $+N$ & Mean & $-N$ & $+N$ & Mean & $-N$ & $+N$ & Mean \\
\hline & \multicolumn{3}{|c|}{ Population $\mathrm{m}^{2}$} & \multicolumn{3}{|c|}{ Height $(\mathrm{cm})-\mathrm{F} 3$} & \multicolumn{3}{|c|}{ Population $\mathrm{m}^{2}$} & \multicolumn{3}{|c|}{ Height $(\mathrm{cm})-F 3$} \\
\hline $\mathrm{Hi}$ & $428 *$ & 426 & $427 \mathrm{~A}$ & 20.7 & 22.5 & $21.6 \mathrm{~A}$ & 426 & 428 & $427 \mathrm{~A}$ & 20.6 & 23.4 & $22.0 \mathrm{~A}$ \\
\hline In & 397 & 391 & 394 B & 19.2 & 20.5 & $19.8 \mathrm{AB}$ & 393 & 403 & $398 \mathrm{AB}$ & 18.9 & 20.0 & $20.0 \mathrm{~B}$ \\
\hline L & 372 & 392 & 382 BC & 18.7 & 20.8 & $19.8 \mathrm{AB}$ & 367 & 387 & 377 B & 18.1 & 19.9 & 19.9 B \\
\hline $\mathrm{VL}$ & 375 & 356 & $365 \mathrm{C}$ & 16.7 & 18.5 & $17.6 \mathrm{~B}$ & 366 & 371 & 367 B & 18.1 & 18.9 & $18.9 \mathrm{~B}$ \\
\hline Mean & 393 ns & 391 & 392 & $18.8 \mathrm{~b}$ & $20.6 \mathrm{a}$ & 19.7 & 388 ns & 397 & 393 & $19.1 \mathrm{~b}$ & $20.2 \mathrm{a}$ & 20.2 \\
\hline \multirow[t]{2}{*}{ CV (\%) } & \multicolumn{3}{|c|}{$4.5 \%$} & \multicolumn{3}{|c|}{$8.7 \%$} & \multicolumn{3}{|c|}{$5.6 \%$} & \multicolumn{3}{|c|}{$6.5 \%$} \\
\hline & \multicolumn{3}{|c|}{$N D V I-F 3$} & \multicolumn{3}{|c|}{ Height $(\mathrm{cm})-\mathrm{F} 8$} & \multicolumn{3}{|c|}{$N D V I-F 3$} & \multicolumn{3}{|c|}{ Height $(\mathrm{cm})-\mathrm{F} 8$} \\
\hline $\mathrm{Hi}$ & 0.42 & 0.51 & $0.47 \mathrm{~A}$ & 29.4 & 30.6 & $30.0 \mathrm{~A}$ & 0.42 & 0.53 & $0.47 \mathrm{~A}$ & 30.5 & 31.3 & $30.8 \mathrm{~A}$ \\
\hline In & 0.37 & 0.47 & $0.42 \mathrm{AB}$ & 26.9 & 26.4 & $26.6 \mathrm{AB}$ & 0.38 & 0.46 & $0.42 \mathrm{AB}$ & 28.2 & 27.8 & $28.0 \mathrm{AB}$ \\
\hline L & 0.35 & 0.45 & $0.40 \mathrm{AB}$ & 24.4 & 24.7 & $24.5 \mathrm{~B}$ & 0.34 & 0.42 & $0.38 \mathrm{BC}$ & 27.5 & 31.0 & $29.3 A B$ \\
\hline $\mathrm{VL}$ & 0.34 & 0.42 & $0.38 \mathrm{~B}$ & 21.8 & 24.0 & $22.9 \mathrm{~B}$ & 0.32 & 0.37 & $0.35 \mathrm{C}$ & 26.4 & 26.5 & 26.5 B \\
\hline Mean & $0.37 \mathrm{~b}$ & $0.46 \mathrm{a}$ & 0.41 & $25.6 \mathrm{~ns}$ & 26.4 & 26.0 & $0.37 \mathrm{~b}$ & $0.45 a$ & 0.41 & $28.1 \mathrm{~ns}$ & 29.2 & 28.6 \\
\hline \multirow[t]{2}{*}{ CV (\%) } & \multicolumn{3}{|c|}{$12.3 \%$} & \multicolumn{3}{|c|}{$10.2 \%$} & \multicolumn{3}{|c|}{$9.7 \%$} & \multicolumn{3}{|c|}{$10.5 \%$} \\
\hline & \multicolumn{3}{|c|}{ NDVI - F 8} & \multicolumn{3}{|c|}{ Height $(\mathrm{cm})$ F 10.5. 1} & \multicolumn{3}{|c|}{$N D V I-F 8$} & \multicolumn{3}{|c|}{ Height $(\mathrm{cm})$ F 10.5. 1} \\
\hline $\mathrm{Hi}$ & 0.53 & 0.61 & $0.57 \mathrm{~A}$ & 68.4 & 79.5 & $73.9 \mathrm{~A}$ & 0.52 & 0.61 & $0.57 \mathrm{~A}$ & 76.5 & 85.9 & $81.2 \mathrm{~ns}$ \\
\hline In & 0.49 & 0.59 & $0.54 \mathrm{AB}$ & 67.1 & 77.1 & $72.1 \mathrm{AB}$ & 0.48 & 0.59 & $0.54 \mathrm{AB}$ & 73.3 & 86.5 & 79.9 \\
\hline L & 0.49 & 0.58 & $0.53 \mathrm{~B}$ & 65.0 & 75.3 & $70.1 \mathrm{~B}$ & 0.47 & 0.52 & $0.49 \mathrm{BC}$ & 72.9 & 85.3 & 79.1 \\
\hline $\mathrm{VL}$ & 0.47 & 0.55 & $0.51 \mathrm{~B}$ & 65.2 & 73.9 & $69.6 \mathrm{~B}$ & 0.46 & 0.49 & $0.48 \mathrm{C}$ & 71.9 & 85.8 & 78.8 \\
\hline Mean & $0.49 \mathrm{~b}$ & $0.58 \mathrm{a}$ & 0.54 & $66.4 \mathrm{~b}$ & $76.4 \mathrm{a}$ & 71.4 & $0.48 \mathrm{~b}$ & $0.55 a$ & 0.52 & 73.7 b & 85.9 a & 79.8 \\
\hline \multirow[t]{2}{*}{ CV (\%) } & \multicolumn{3}{|c|}{$4.6 \%$} & \multicolumn{3}{|c|}{$3.0 \%$} & & $6.9 \%$ & & & $3.6 \%$ & \\
\hline & & $/ I-F 10$ & & & iber of $t$ & & & II-F 10 & & & ber of $t$ & \\
\hline $\mathrm{Hi}$ & 0.73 & 0.83 & $0.78 \mathrm{~A}$ & 3.25 & 3.56 & $3.41 \mathrm{~ns}$ & 0.79 & 0.89 & $0.84 \mathrm{~A}$ & 3.25 & 3.75 & $3.5 \mathrm{~A}$ \\
\hline In & 0.72 & 0.78 & $0.75 \mathrm{~A}$ & 3.02 & 3.45 & 3.24 & 0.78 & 0.89 & $0.83 \mathrm{AB}$ & 3.17 & 3.61 & $3.39 A B$ \\
\hline L & 0.69 & 0.77 & $0.73 \mathrm{AB}$ & 2.92 & 3.45 & 3.18 & 0.75 & 0.88 & $0.81 \mathrm{AB}$ & 2.83 & 3.55 & $3.19 \mathrm{~B}$ \\
\hline $\mathrm{VL}$ & 0.67 & 0.71 & $0.69 \mathrm{~B}$ & 3.01 & 3.4 & 3.20 & 0.73 & 0.86 & $0.79 \mathrm{~B}$ & 2.87 & 3.36 & $3.12 \mathrm{~B}$ \\
\hline Mean & $0.70 \mathrm{~b}$ & $0.77 \mathrm{a}$ & 0.74 & $3.05 \mathrm{~b}$ & $3.46 \mathrm{a}$ & 3.26 & $0.76 \mathrm{~b}$ & $0.88 \mathrm{a}$ & 0.82 & $3.03 \mathrm{~b}$ & $3.57 \mathrm{a}$ & 3.30 \\
\hline CV (\%) & & $5.1 \%$ & & & $6.8 \%$ & & & $3.7 \%$ & & & $6.4 \%$ & \\
\hline
\end{tabular}

*Values represent the average of four experimental units $(n o=4)$, where each unit was obtained from the average of three experimental locations. Means followed by different capital letters between vigor levels and also different lowercase between $\mathrm{N}$ fertilization levels mean a significant difference in the mean comparison with Tukey's test at 5\% probability. ns means no significance in the analysis of variance (ANOVA). 
Table 2. Dry matter weight values (DMW - g) found in stages 3, 8, 10.5.1 and 11.1 on the Feekes scale in wheat plants of the CD 150 early cycle (Cycle -) and medium cycle Tbio Mestre (Cycle) genotype + ) originated from seeds with high vigor (Hi), intermediate vigor (In), low (L) and very low vigor $(\mathrm{VL})$, which were fertilized $(+\mathrm{N})$ and not fertilized (-N) with nitrogen topdressing.

\begin{tabular}{|c|c|c|c|c|c|c|c|c|c|c|c|c|}
\hline \multirow{3}{*}{ Vigor } & \multicolumn{6}{|c|}{ Cycle - } & \multicolumn{6}{|c|}{ Cycle + } \\
\hline & $-N$ & $+\mathrm{N}$ & Mean & $-N$ & $+N$ & Mean & $-N$ & $+N$ & Mean & $-N$ & $+\mathrm{N}$ & Mean \\
\hline & \multicolumn{3}{|c|}{$\mathrm{DMW}(\mathrm{g})-\mathrm{F} 3$} & \multicolumn{3}{|c|}{$\mathrm{DMW}(\mathrm{g})-\mathrm{F} 8$} & \multicolumn{3}{|c|}{ DMW- F3 } & \multicolumn{3}{|c|}{$\mathrm{DMW}(\mathrm{g})-\mathrm{F} 8$} \\
\hline $\mathrm{Hi}$ & $8.31^{*}$ & 8.44 & $9.07 \mathrm{~A}$ & 19.39 & 29.27 & $24.33 \mathrm{~A}$ & 8.40 & 10.3 & $9.35 \mathrm{~A}$ & 21.17 & 35.89 & $28.53 \mathrm{~A}$ \\
\hline $\ln$ & 7.81 & 9.07 & $8.44 \mathrm{~A}$ & 17.94 & 27.25 & $22.60 \mathrm{AB}$ & 7.03 & 8.70 & $7.86 \mathrm{AB}$ & 19.11 & 34.29 & $26.70 A B$ \\
\hline L & 6.36 & 7.73 & $7.04 \mathrm{~B}$ & 15.29 & 25.69 & $20.49 \mathrm{BC}$ & 7.38 & 8.15 & 7.77 BC & 16.27 & 28.41 & $22.34 \mathrm{BC}$ \\
\hline VL & 5.50 & 6.81 & $6.16 \mathrm{~B}$ & 16.03 & 23.36 & $19.69 \mathrm{C}$ & 6.85 & 7.09 & $6.97 \mathrm{C}$ & 16.31 & 25.40 & $20.86 \mathrm{C}$ \\
\hline Mean & $7.00 \mathrm{~b}$ & $8.36 \mathrm{a}$ & 7.68 & $17.17 \mathrm{~b}$ & $26.39 a$ & 21.78 & $7.41 b$ & $8.56 \mathrm{a}$ & 7.99 & $18.21 \mathrm{~b}$ & $31.00 \mathrm{a}$ & 24.61 \\
\hline \multirow[t]{2}{*}{ CV (\%) } & \multicolumn{3}{|c|}{$12.0 \%$} & \multicolumn{3}{|c|}{$9.2 \%$} & \multicolumn{3}{|c|}{$15.4 \%$} & \multicolumn{3}{|c|}{$14.5 \%$} \\
\hline & \multicolumn{3}{|c|}{$\mathrm{DMW}(\mathrm{g})-\mathrm{F}$ 10.5. 1} & \multicolumn{3}{|c|}{$\mathrm{DMW}(\mathrm{g})-\mathrm{F} 11.1$} & \multicolumn{3}{|c|}{$\mathrm{DMW}(\mathrm{g})-\mathrm{F}$ 10.5. 1} & \multicolumn{3}{|c|}{$\mathrm{DMW}(\mathrm{g})-\mathrm{F} 11.1$} \\
\hline $\mathrm{Hi}$ & 85.37 & 92.90 & 89.14 ns & 172.86 & 213.10 & $192.98 \mathrm{~A}$ & 95.22 & 115.14 & $105.18 \mathrm{AB}$ & 183.03 & 229.55 & 206.68 A \\
\hline In & 84.53 & 92.13 & 88.33 & 160.33 & 189.67 & $175.00 \mathrm{AB}$ & 94.80 & 119.09 & $106.94 \mathrm{~A}$ & 161.01 & 203.21 & $182.11 \mathrm{AB}$ \\
\hline L & 80.13 & 84.11 & 82.12 & 138.47 & 182.35 & $160.41 \mathrm{BC}$ & 90.30 & 111.79 & $101.05 \mathrm{AB}$ & 148.38 & 186.15 & 167.26 B \\
\hline VL & 79.21 & 83.04 & 81.13 & 135.62 & 168.88 & $152.25 \mathrm{C}$ & 87.00 & 110.28 & 98.64 B & 146.23 & 169.91 & 158.07 B \\
\hline Mean & $82.31 \mathrm{~b}$ & $88.04 \mathrm{a}$ & 85.18 & $151.82 \mathrm{~b}$ & $188.50 \mathrm{a}$ & 170.16 & $91.83 \mathrm{~b}$ & $114.08 \mathrm{a}$ & 102.95 & $159.86 \mathrm{~b}$ & $197.21 \mathrm{a}$ & 178.53 \\
\hline CV (\%) & \multicolumn{3}{|c|}{$7.6 \%$} & \multicolumn{3}{|c|}{$9.4 \%$} & \multicolumn{3}{|c|}{$4.7 \%$} & \multicolumn{3}{|c|}{$11.9 \%$} \\
\hline
\end{tabular}

*Values represent the average of four experimental units $(n o=4)$, where each unit was obtained from the average of three experimental locations. Means followed by different capital letters between vigor levels and also different lowercase between $\mathrm{N}$ fertilization levels mean a significant difference in the mean comparison with Tukey's test at $5 \%$ probability. ns means no significance in the analysis of variance (ANOVA).

Despite the evident benefits to establishment and throughout the plant cycle, seed vigor did not influence the yield of the two genotypes, a variable only affected by $N$ (Table 3 ). The use of this element in topdressing fertilization provided an increase in seed yield by and $11 \%$ for early and medium cycle genotypes, respectively. This increase in yield caused by topdressing nitrogen fertilization is supported by the increments provided by this element to the following yield components: number of spikelets per ear (NSpE), number of seeds per ear (NSE) - the latter only in the early cycle genotype - and in the weight of seeds per ear (WSE). Although it did not affect yield, plants with early and medium cycle genotypes originated from high-vigor seeds provided increases of 19 and 14\%, respectively, in WSE compared to seeds with very low vigor. Abati et al. (2018) also found that plants originating from high-vigor seeds had better performance at the end of the cycle. These same authors suggested that greater seed yield is linked to greater seedling establishment, plant growth and development in the early phenological stages.

The evaluation of all results based on principal component analysis (PCA) - which had $64 \%$ of the total variance explained in the first two components - highlights the impacts caused by seed quality (Figure 2a). This variability (>60\%) reaches an empirical threshold highlighted by Yang et al. (2009) for the practical evaluation of biplots. The treatments positioned beside component 2 are characterized by superior performance, and are strongly associated with the biomass accumulation variables - such as DMW - and with the yield components. In fact, DMW in the stages - benefited by the vigor of the seeds throughout the entire cycle - showed a positive correlation with seed yield (Figure $2 b$ ).

The effect of the seed vigor factor has been evidenced with the use of the multivariate approach. Plants of the early cycle genotype from high-vigor seeds that were fertilized with nitrogen only at sowing were grouped (based on their overall performance) along with plants from low-vigor seeds that were fertilized with nitrogen at sowing and with top dressing fertilization. This finding - not verified using the classical analysis - allowed identifying the best treatments and associating them with the variables with the greatest contribution to this item. The potential use of 
this analysis was also highlighted by Bertolli et al. (2013). When questioning the difficulty in finding an indicator for water stress in plants, these same authors concluded that multivariate cross-scale analysis is an appropriate method to establish models that will allow a systemic understanding of the complex interactions between plants and their changing environment.

As in PCA, data transformation and cluster formation via Euclidean distance was an interesting tool to highlight the impacts of seed quality on the performance of wheat plants (Figure 2c). The analysis of the results - distributed on a heat map - enables to separate the treatments into three groups. In one of the three clusters, the performance of plants of the two genotypes originated from high-vigor seeds and not fertilized with $\mathrm{N}$ in topdressing application was similar to that of plants from the early genotype originating from seeds with intermediate, low and also very low vigor. This shows that the impacts of using high-vigor wheat seeds go beyond plant stand establishment - as properly highlighted by Abati et al. (2018), and cover growth attributes that allow to highlight their importance as much as the use of nitrogen fertilization.

Table 3. Yield values (t.ha-1), number of spikelets per ear (NSpE), number of seeds per ear (NSE) and per spikelet (NSSp), as well as weight of seeds per ear (WSE) and harvest index (HI) of wheat plants from CD 150 early cycle genotype (Cycle -) and medium cycle Tbio Mestre (Cycle + ) originated from seeds with high (Hi), intermediate $(\operatorname{In})$, low $(\mathrm{L})$ and very low $(\mathrm{VL})$ vigor, which were fertilized $(+\mathrm{N})$ and not fertilized $(-\mathrm{N})$ with nitrogen topdressing.

\begin{tabular}{|c|c|c|c|c|c|c|c|c|c|c|c|c|}
\hline \multirow{3}{*}{ Vigor } & \multicolumn{6}{|c|}{ Cycle - } & \multicolumn{6}{|c|}{ Cycle + } \\
\hline & $-N$ & $+N$ & Mean & $-N$ & $+N$ & Mean & $-N$ & $+N$ & Mean & $-N$ & $+\mathrm{N}$ & Mean \\
\hline & \multicolumn{3}{|c|}{ Yield (t.ha-1) } & \multicolumn{3}{|c|}{ NSpE } & \multicolumn{3}{|c|}{ Yield (t.ha-1) } & \multicolumn{3}{|c|}{$\mathrm{NSpE}$} \\
\hline $\mathrm{Hi}$ & $3.63 *$ & 3.95 & $3.79 \mathrm{~ns}$ & 14.3 & 15.5 & $14.7 \mathrm{~ns}$ & 3.69 & 4.06 & $3.88 \mathrm{~ns}$ & 16.2 & 17.8 & $17.0 \mathrm{~ns}$ \\
\hline $\ln$ & 3.39 & 3.76 & 3.54 & 14.3 & 15.1 & 14.9 & 3.54 & 3.87 & 3.70 & 16.9 & 17.3 & 17.18 \\
\hline L & 3.31 & 3.75 & 3.53 & 14.7 & 15.1 & 14.7 & 3.34 & 3.92 & 3.63 & 16.0 & 17.2 & 16.6 \\
\hline VL & 3.33 & 3.53 & 3.43 & 14.7 & 14.7 & 14.9 & 3.27 & 3.71 & 3.49 & 15.8 & 17.3 & 16.6 \\
\hline Mean & $3.41 \mathrm{~b}$ & $3.74 \mathrm{a}$ & 3.57 & $14.5 \mathrm{~b}$ & $15.1 \mathrm{a}$ & 14.8 & $3.46 \mathrm{~b}$ & $3.89 a$ & 3.67 & $16.2 \mathrm{~b}$ & $17.4 \mathrm{a}$ & 16.8 \\
\hline \multirow[t]{2}{*}{ CV (\%) } & \multicolumn{3}{|c|}{$9.4 \%$} & \multicolumn{3}{|c|}{$3.9 \%$} & \multicolumn{3}{|c|}{$9.2 \%$} & \multicolumn{3}{|c|}{$3.4 \%$} \\
\hline & \multicolumn{3}{|c|}{ NSE } & \multicolumn{3}{|c|}{ NSSp } & \multicolumn{3}{|c|}{ NSE } & \multicolumn{3}{|c|}{ NSSp } \\
\hline $\mathrm{Hi}$ & 37.7 & 39.6 & $38.6 \mathrm{~ns}$ & 2.62 & 2.56 & $2.59 \mathrm{~ns}$ & 41.1 & 43.3 & $42.2 \mathrm{~ns}$ & 2.54 & 2.42 & $2.48 \mathrm{~ns}$ \\
\hline $\ln$ & 37.3 & 38.8 & 38.13 & 2.60 & 2.57 & 2.58 & 40.6 & 41.8 & 41.2 & 2.39 & 2.41 & 2.40 \\
\hline L & 38.1 & 39.5 & 38.8 & 2.59 & 2.60 & 2.59 & 39.8 & 41.4 & 40.6 & 2.49 & 2.40 & 2.45 \\
\hline VL & 35.4 & 37.8 & 36.6 & 2.40 & 2.57 & 2.48 & 38.9 & 40.9 & 39.9 & 2.45 & 2.35 & 2.40 \\
\hline Mean & $37.1 \mathrm{~b}$ & $38.9 \mathrm{a}$ & 38.0 & $2.55 \mathrm{~ns}$ & 2.57 & 2.56 & $40.1 \mathrm{~ns}$ & 41.8 & 41.0 & $2.47 \mathrm{~ns}$ & 2.40 & 2.43 \\
\hline \multirow[t]{2}{*}{ CV (\%) } & \multicolumn{3}{|c|}{$5.9 \%$} & \multicolumn{3}{|c|}{$5.4 \%$} & \multicolumn{3}{|c|}{$5.8 \%$} & \multicolumn{3}{|c|}{$7.0 \%$} \\
\hline & \multicolumn{3}{|c|}{ WSE } & \multicolumn{3}{|c|}{$\mathrm{HI}$} & \multicolumn{3}{|c|}{ WSE } & \multicolumn{3}{|c|}{$\mathrm{HI}$} \\
\hline $\mathrm{Hi}$ & 91.1 & 103.3 & $97.2 \mathrm{~A}$ & 0.48 & 0.49 & $0.49 \mathrm{~ns}$ & 103.4 & 103.6 & $103.5 \mathrm{~A}$ & 0.47 & 0.48 & $0.48 \mathrm{~ns}$ \\
\hline In & 79.9 & 90.6 & $85.2 \mathrm{~B}$ & 0.46 & 0.47 & 0.46 & 88.7 & 99.4 & $94.0 \mathrm{AB}$ & 0.45 & 0.46 & 0.46 \\
\hline L & 80.0 & 88.4 & $84.2 \mathrm{~B}$ & 0.43 & 0.44 & 0.44 & 87.4 & 103.3 & $95.4 A B$ & 0.43 & 0.46 & 0.44 \\
\hline $\mathrm{VL}$ & 78.4 & 78.6 & $78.5 \mathrm{~B}$ & 0.44 & 0.44 & 0.44 & 78.8 & 98.4 & $88.6 \mathrm{~B}$ & 0.43 & 0.46 & 0.45 \\
\hline Mean & $82.3 \mathrm{~b}$ & $90.2 \mathrm{a}$ & 86.3 & $0.45 \mathrm{~ns}$ & 0.46 & 0.46 & $89.6 \mathrm{~b}$ & $101.2 \mathrm{a}$ & 95.4 & $0.45 \mathrm{~ns}$ & 0.47 & 0.46 \\
\hline CV (\%) & \multicolumn{3}{|c|}{$9.6 \%$} & \multicolumn{3}{|c|}{$7.7 \%$} & \multicolumn{3}{|c|}{$7.3 \%$} & \multicolumn{3}{|c|}{$6.7 \%$} \\
\hline
\end{tabular}

*Values represent the average of four experimental units $(n o=4)$, where each unit was obtained from the average of three experimental locations. Means followed by different capital letters between vigor levels and also different lowercase between $\mathrm{N}$ fertilization levels mean a significant difference in the mean comparison with Tukey's test at $5 \%$ probability. ns means no significance in the analysis of variance (ANOVA). 


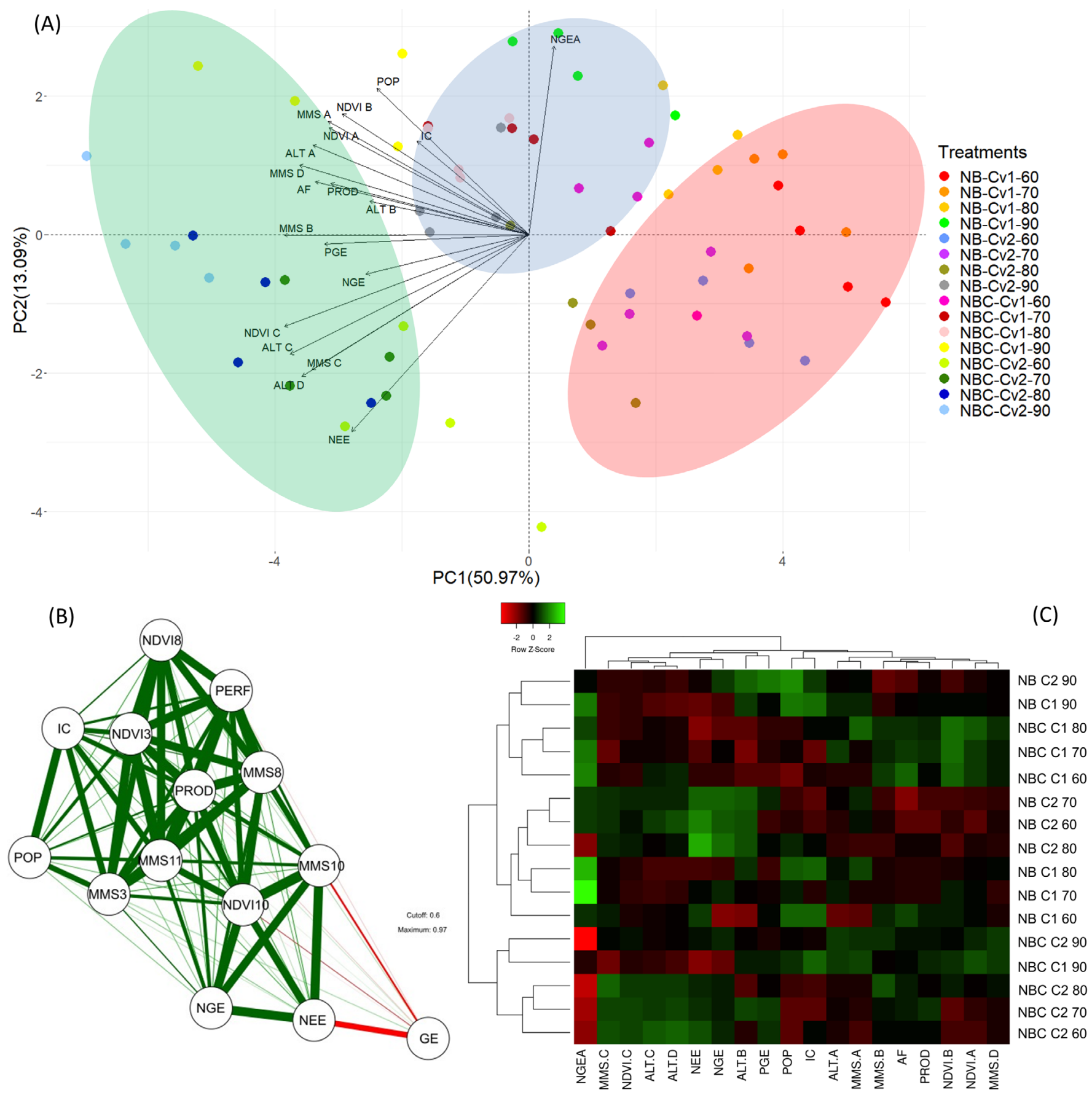

Figure 2. Analysis of principal components (A), correlation (B) and heat map (C) from variables evaluated along the wheat plant cycle of an early cycle (Cv 1) and a medium cycle (Cv) cultivar 2) from seeds with high vigor (90), intermediate vigor (80), low vigor (70) and very low vigor (60), fertilized with nitrogen only at sowing (NF), and also at sowing and with topdressing fertilization (TNF). The variables that constituted this analysis were plant population (POP), number of tillers (NT), height (HGT) and normalized difference vegetation index, the latter two found in stages 3 (A), 8 (B) and 10.5.1 (C) on the Feekes scale. These same scales were used as reference to determine dry matter weight (DMW), which was also evaluated in stage 11.1 (D). Yield (YLD), number of spikelets per ear (NSpE), number of seeds per ear (NSE) and per spikelet (NSSp), as well as weight of seeds per spike (WSE) and harvest index (HI) were also covered in this assessment. 


\section{CONCLUSIONS}

High-vigor seeds provide better establishment by promoting a larger population and benefiting growth from the beginning of tillering until the beginning of the reproductive stage. This performance is improved by high-vigor seeds regardless of topdressing nitrogen fertilization. The cluster stratification obtained by the Euclidean distance leads to conclusion that plants that had not received topdressing nitrogen fertilization, originated from high-vigor seeds, performed similarly to plants from high-vigor seeds that had been fertilized with nitrogen.

\section{ACKNOWLEDGMENTS}

The authors would like to thank the Coordination for the Improvement of Higher Education Personnel - Brazil (CAPES) - Funding Code 001 - for the scholarships provided to the corresponding author and the fourth author.

\section{REFERENCES}

ABATI, J.; BRZEZINSKI, C.R.; FOLONI, J.S.S.; ZUCARELI, C.; BASSOI, M.C.; HENNING, F.A. Seedling emergence and yield performance of wheat cultivars depending on seed vigor and sowing density. Journal of Seed Science, v.39, n.1, p.58-65, 2017. http://dx.doi. org/10.1590/2317-1545v39n1171002

ABATI, J.; BRZEZINSKI, C.R.; ZUCARELI, C.; FOLONI, J.S.S.; HENNING, F.A. Growth and yield of wheat in response to seed vigor and sowing densities. Revista Caatinga, v.31, n.4, p.891-899, 2018. http://dx.doi.org/10.1590/1983-21252018v31n411rc

BABICKI, S.; ARNDT, D.; MARCU, A.; LIANG, Y.; GRANT, J.R. MACIEJEWSKI, A.; WISHART, D.S. Heatmapper: web-enabled heat mapping for all. Nucleic Acids Research, v. 44, n.W1, p.W147-W153, 2016. https://doi.org/10.1093/nar/gkw419

BAGATELI, J.R.; DÖRR, C.S.; SCHUCH, L.O.B.; MENEGHELLO, G.E. Productive performance of soybean plants originated from seed lots with increasing vigor levels. Journal of Seed Science, v.41, n.2, p.151-159, 2019. http://dx.doi.org/10.1590/2317-1545v41n2199320

BERTOLLI, S.C.; MAZZAFERA, P.; SOUZA, G.M. Why is it so difficult to identify a single indicator of water stress in plants? A proposal for a multivariate analysis to assess emergent properties. Plant Biology, v.16, n3, p.578-585, 2013. https://doi.org/10.1111/plb.12088

BOHN, A.; BORTOLIN, G.S.; CASTELLANOS, C.I.S.; REIS, B.B.; SUÑÉ, A.S.; BONOW, J.F.L.; PEDROSO, C.E.S.; MITTELMANN, A. Nitrogen fertilization of self-seeding Italian ryegrass: effects on plant structure, forage and seed yield. Ciência Rural, v.50, n.6, e20190510, 2020. https://doi.org/10.1590/0103-8478cr20190510

CARDOSO, C.P.; BAZZO, J.H.B.; MARINHO, J.L.; ZUCARELI, C. Effect of seed vigor and sowing densities on the yield and physiological potential of wheat seeds. Journal of Seed Science, v.43, e202143002, 2021. http://dx.doi.org/10.1590/2317-1545v43241586

CAVERZAN, A.; GIACOMIN, R.; MÜLLER, M.; BIAZUS, C.; LÂNGARO, N.C.; CHAVARRIA, G. How does seed vigor affect soybean yield components?. Agronomy Journal, v.110, n.4, p.1318-1327, 2018. https://doi.org/10.2134/agronj2017.11.0670

CORBINEAU, F. Markers of seed quality: from present to future. Seed Science Research, v.22, S1-S68, 2012. https://doi.org/10.1017/ S0960258511000419

EBONE, L.A.; CAVERZAN, A.; TAGLIARI, A.; CHIOMENTO, J.L.T.; SILVEIRA, D.C.; CHAVARRIA, G. Soybean seed vigor: Uniformity and growth as key factors to improve yield. Agronomy, v.10, n.4, 545, 2020. https://doi.org/10.3390/agronomy10040545

EMBRAPA. Empresa Brasileira de Pesquisa Agropecuaria. Sistema Brasileiro de classificação do solo. Brasília, 2013, 353p. http:// livimagens.sct.embrapa.br/amostras/00053080.pdf

FERREIRA, D.F. SISVAR: A computer analysis system to fixed effects split plot type designs. Revista Brasileira de Biometria, v.37, n.4, p.529-535, 2019. https://doi.org/10.28951/rbb.v37i4.450

FINCH-SAVAGE, W.E.; BASSEL, G.W. Seed vigour and crop establishment: extending performance beyond adaptation. Journal of Experimental Botany, v.67, n.3, p.567-591, 2016. https://doi.org/10.1093/jxb/erv490

LARGE, E.C. Growth stages in cereals. Ilustration of Feekes scale. Plant Physiology, v.3, p.128-129, 1954. https://doi. org/10.1111/j.1365-3059.1954.tb00716.x 
LÓPEZ, O.E.; GONZALEZ, E.; DE LLAMAS, P.A.; MOLINAS, A.S.; FRANCO, E.S.; GARCIA, S.; RIOS, E. Reconocimiento de suelos y capacidad de uso de las tierras: Región Oriental. Asunción, MAG/Dirección de Ordenamiento Ambiental/Banco Mundial, 1995. 28p. http://www.scielo.br/scielo.php?script=sci_nlinks\&ref=000114 \&pid=S01000683200700060002300016\&lng=pt

MARINHO, J.L.; SILVA, S.R.; SOUZA, D.N.; FONSECA, I.C.B.; BAZZO, J.H.B.; ZUCARELI, C. Wheat yield and seed physiological quality affected by initial seed vigor, sowing density, and environmental conditions. Semina: Ciências Agrárias, v.42, n.3, p.1595-1614, 2021. https://doi.org/ 10.5433/1679-0359.2021v42n3Supl1p1595

PANG, J.; PALTA, J.A.; REBETZKE, G.J.; MILROY, S.P. Wheat genotypes with high early vigour accumulate more nitrogen and have higher photosynthetic nitrogen use efficiency during early growth. Functional Plant Biology, v.41, n.2, p.215-222, 2013. https://doi. org/10.1071/FP13143

PAVINATO, P.S.; PAULETTI, V.; MOTTA, A.C.V.; MOREIRA, A. Manual de adubação e calagem para o Estado do Paraná. Curitiba: SBCS/ NEPAR. 2017, 482p.

PESKE, S.T.; BARROS, A.C.S.A.; SCHUCH, L.O.B. Produção de sementes In: PESKE, S.T; VILLELA, F.A.; MENEGHELLO, G. E. (Eds). Sementes: fundamentos científicos e tecnológicos. Pelotas: EDITORA UNIVERSITÁRIA/UFPel, 2012. p.13-103.

R CORE TEAM. R: A language and environment for statistical computing. R Foundation for Statistical Computing, Vienna, Austria, 2018. http://www.R-project.org/

YANG, R.C.; CROSSA, J.; CORNELIUS, P.L.; BURGUEÑO, J. Biplot analysis of genotype $x$ environment interaction: Proceed with caution. Crop Science, v.49, n.5, p.1564-1576, 2009. https://doi.org/10.2135/cropsci2008.11.0665 use, distribution, and reproduction in any medium, provided the original work is properly cited. 